\title{
Endovascular stenting in the management of malignant superior vena cava obstruction: comparing safety, effectiveness, and outcomes between primary stenting and salvage stenting
}

\author{
ST Leung *, Tony HT Sung, Alvin YH Wan, KW Leung, WK Kan
}

\section{A B S T R A C T}

Objective: To compare the safety, effectiveness, and outcomes of primary stenting and salvage stenting for malignant superior vena cava obstruction.

Design: Case series with internal comparison.

Setting: Regional hospital, Hong Kong.

Patients: A total of 56 patients with malignant superior vena cava obstruction underwent 59 stentings from 1 May 1999 to 31 January 2014. Patients' characteristics, procedural details, and outcomes were retrospectively reviewed. Of the 56 patients, 33 had primary stenting before conventional therapy and 23 had salvage stenting after failure of conventional therapy. Statistical analyses were made by Fisher's exact test and Mann-Whitney $U$ test.

Results: Primary lung carcinoma was the most common cause of malignant superior vena cava obstruction (primary stenting, 22 patients; salvage stenting, 16 patients; $\mathrm{P}=0.768$ ), followed by metastatic lymphadenopathy. Most patients had superior vena cava obstruction only (primary stenting, 16 patients; salvage stenting, 15 patients; $\mathrm{P}=0.633$ ), followed by additional right brachiocephalic vein involvement. Wallstents (Boston Scientific, Natick [MA], US) were used in all patients. Technical success was achieved in all but two patients, one in each group $(\mathrm{P}=1.000)$. Only one stent placement was required in most patients (primary stenting, 28 patients; salvage stenting, 20 patients; $\mathrm{P}=0.726$ ). Procedure time was comparable in both groups (mean time: primary
$\mathrm{P}=0.526)$. Symptomatic relief was achieved in most patients (primary stenting, 32 patients; salvage stenting, 23 patients; $\mathrm{P}=0.639)$. In-stent restenosis and bleeding were the commonest complications (primary stenting, 6 and 1 patients, respectively; salvage stenting, 2 and 2 patients, respectively). Nine patients required further treatment for symptom recurrence (primary stenting, 6 patients; salvage stenting, 3 patients; $\mathrm{P}=0.725$ ).

Conclusion: Endovascular stenting is safe and effective for relieving malignant superior vena cava obstruction. No statistically significant differences in number of stents, success rates, procedure times, symptom relief rates, complication rates, and reprocedure rates were found between primary stenting and salvage stenting.

\section{Hong Kong Med J 2015;21:426-34}

DOI: $10.12809 / \mathrm{hkmj} 144363$

ST Leung *, MB, BS, FRCR

THT Sung, FRCR, FHKAM (Radiology)

AYH Wan, FRCR, FHKAM (Radiology)

KW Leung, FRCR, FHKAM (Radiology)

WK Kan, FRCR, FHKAM (Radiology)

Department of Radiology, Pamela Youde Nethersole Eastern Hospital, Chai Wan, Hong Kong

stenting, 89 minutes; salvage stenting, 84 minutes; * Corresponding author: baryleung@hotmail.com

New knowledge added by this stud

- Endovascular stenting is safe and effective for relieving malignant superior vena cava obstruction (SVCO) in both primary stenting and salvage stenting settings.

- Direct comparison between primary stenting and salvage stenting for safety, effectiveness, and outcomes of superior vena cava (SVC) stenting showed no significant differences in number of stents required, success rates, procedure times, symptom relief rates, complication rates, and re-procedure rates between the two groups.

Implications for clinical practice or policy

Primary SVC stenting should be considered for patients at their initial presentation with SVCO before conventional therapy by radiotherapy and/or chemotherapy.

- Salvage SVC stenting remains a safe and effective treatment for patients with SVCO after failure of radiotherapy and/or chemotherapy. 


\section{Introduction}

Superior vena cava (SVC) syndrome encompasses a constellation of symptoms and signs secondary to superior vena cava obstruction (SVCO). The syndrome frequently occurs secondary to extrinsic SVC compression, mostly from malignant causes, due to its low internal venous pressure and location within the rigid structures in the mediastinum. The resulting elevated venous pressure in the upper body causes oedema of the head, neck, and upper extremities. Oedema in the airway may cause lifethreatening airway obstruction, and cerebral oedema may result in confusion and coma. There is also decreased venous return causing haemodynamic compromise. These all result in the significant morbidity and mortality associated with SVCO. ${ }^{1,2}$

Since its first description by Charnsangavej et al in 1986, ${ }^{3}$ SVC stenting has gained increasing popularity in the management of SVCO due to its rapid and effective relief of symptoms compared with conventional therapy by radiotherapy and chemotherapy. A systematic review by Rowell and Gleeson ${ }^{4}$ concluded that stenting is the most effective and rapid treatment for relieving SVCO symptoms, providing overall symptomatic relief in $95 \%$ of patients with an $11 \%$ symptom recurrence rate. Radiotherapy and chemotherapy, however, could only achieve symptomatic relief in $60 \%$ to $77 \%$ of patients, with $17 \%$ to $19 \%$ of patients having symptom recurrence. ${ }^{4}$

Stenting of SVC is traditionally offered as a salvage therapy after failure of conventional therapy. In recent years, an increasing number of hospitals have begun to consider primary stenting as a firstline treatment prior to conventional therapy due to its promising results. ${ }^{2,5}$ However, there is currently a lack of studies directly comparing the results of primary stenting before conventional therapy and salvage stenting after failure of conventional therapy. In addition, previous studies evaluating SVC stenting are often limited by a small sample size and lack of long-term follow-up. Only a few case series of more than 50 patients are currently available in the literature. ${ }^{6-11}$

With the aim of comparing the safety, effectiveness, and outcomes between patients undergoing primary stenting before conventional therapy and salvage stenting after failure of conventional therapy, we report our 15 years' experience in the management of malignant SVCO with Wallstent endoprosthesis (Boston Scientific, Natick [MA], US).

\section{Methods}

A retrospective review of the indications, clinical characteristics, procedures, complications, and outcomes was performed for all patients with clinical symptoms of SVCO who underwent SVC stenting at

\section{血管內支架置入術治療惡性上腔靜脈阻塞：} 比較主支架和補救性支架的安全性、有效性和 治療結果

\author{
梁肇庭、宋咸東、尹宇瀚、梁錦榮、簡偉權
}

目的：比較主支架和補救性支架於治療惡性上腔靜脈阻塞的安全性 有效性和治療結果。

設計：病例系列的內部比較。

安排：香港一所分區醫院。

患者：1999年5月1日至2014年1月31日期間共有56名（59例）惡性 上腔靜脈阻塞症患者。根據患者特徵、手術細節和結果進行回顧性分 析。56名患者中, 33 人在進行常規治療前曾接受主支架置入術, 另 23 人因常規治療失敗而接受補救性支架置入術。研究並使用費氏精確檢 定法和曼一惠特尼U檢驗進行統計學分析。

結果：原發性肺癌是最常見的病因（主支架 22 人, 補救性支架 16 人； $\mathrm{P}=0.768 ）$, 其次是轉移性淋巴結腫大。大多數患者只有上腔靜 脈阻塞（主支架 16 人, 補救性支架 15 人; $\mathrm{P}=0.633$ ) , 其次是累及右 側頭臂靜脈。所有患者均使用Wallstent支架。除了兩名患者, 其餘患 者均成功進行手術（ $\mathrm{P}=1.000 ） 。 大$ 多數患者只須使用一個支架（主 支架 28 人, 補救性支架 20 人; $\mathrm{P}=0.726$ ) 。兩組的手術時間相若（平 均時間：主支架 89 分鐘, 補救性支架 84 分鐘; $\mathrm{P}=0.526)$ 。大多數患 者的症狀均有緩解（主支架 32 人, 補救性支架 23 人; $\mathrm{P}=0.639$ ）。支 架內再狹窄和出血是最常見的併發症 (主支架分別有 6 人和 1 人; 補救 性支架分別有 2 人和 2 人）。9名患者因復發須接受進一步治療（主支 架 6 人, 補救性支架 3 人； P $=0.725$ ）。

結論：血管內支架置入術對於緩解惡性上腔靜脈阻塞既安全又有效。 不論在支架數量、成功率、手術時間、症狀緩解率、併發率和再手術 率方面, 主支架和補救性支架置入術均無顯著差異。

a single hospital in Hong Kong from 1 May 1999 to 31 January 2014. Patients were identified from the departmental internal records and the radiology information system. All patients had computed tomography performed prior to stent placement, which revealed unresectable malignant SVCO. Patients' medical and procedural records were retrospectively reviewed by a radiologist who was a Fellow of the Royal College of Radiologists with subspecialty training in interventional radiology, and who was blinded to whether the patient was receiving primary stenting or salvage stenting during the review of patients' outcomes. The followup period was considered as being from the day of the procedure to the day of the latest information or death, with the end of data collection fixed on 1 May 2014. This study was approved by the local Institutional Review Board.

Patients were categorised into either the primary stenting group or the salvage stenting group. Patients in the primary stenting group had SVC stenting performed at initial presentation of SVCO before any radiotherapy and/or chemotherapy. Patients in the salvage stenting group had SVC 
stenting performed after failure of radiotherapy and/or chemotherapy, which was defined as newly developed or worsening SVCO symptoms despite the use of radiotherapy and/or chemotherapy. The primary stenting group comprised 33 patients with 35 SVC stentings done and the salvage stenting group comprised 23 patients with 24 SVC stentings performed.

Stent placement was performed under local anaesthesia in an angiography suite with cardiopulmonary monitoring for all patients after obtaining informed consent. Pre-procedure superior vena cavograms were performed for assessment of site, length, degree of stenosis, and planning of stent placement. Wallstent endoprostheses were used in all patients. Intravenous heparin was administered before stent placement.

The stenoses were first negotiated with a guidewire. Placements of Wallstents across the stenoses were then performed. Balloon angioplasty was performed before and/or after stent placement if considered necessary by the performing interventional radiologist. Stent position and patency were confirmed by post-procedural superior vena cavogram, which also excluded any venous rupture (Fig 1).
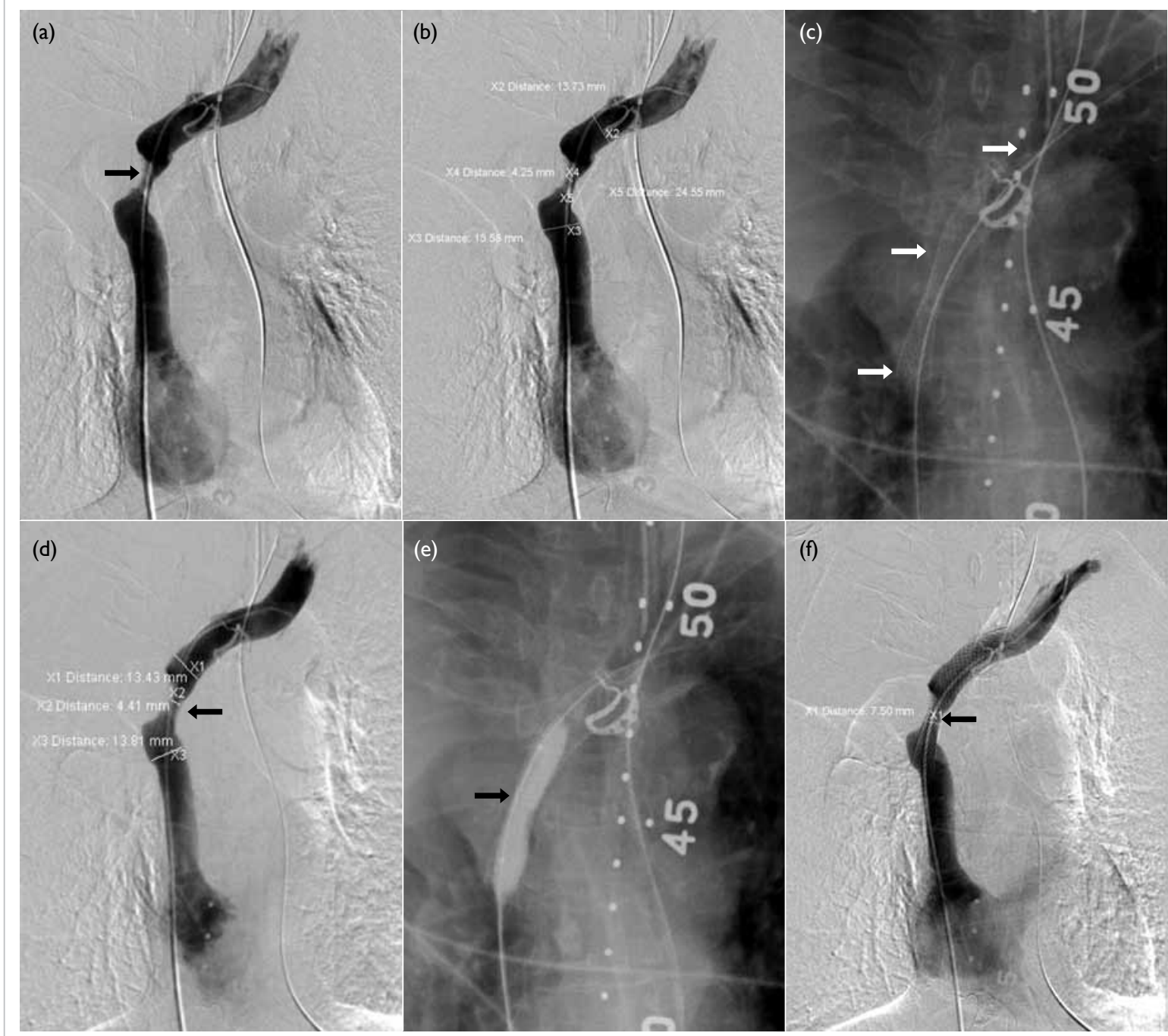

FIG I. Superior vena cavograms showing superior vena cava (SVC) stenting of a 70-year-old woman who developed SVC obstruction complicating a primary lung carcinoma

(a) Superior vena cavogram performed via the right femoral approach shows a malignant stricture with shouldering at the upper SVC involving the left brachiocephalic vein (arrow); (b) measurements are being made for planning of stent placement in the SVC. The narrowest segment of the stricture measured $4.25 \mathrm{~mm}$; (c) a $16 \times 60-\mathrm{mm}$ Wallstent endoprosthesis is deployed across the stricture with the cranial end at the left brachiocephalic vein and the caudal end at the lower SVC (arrows); (d) post-stenting superior vena cavogram shows moderate residual stricture with flow limitation (arrow). The narrowest segment of the stricture measured $4.4 \mathrm{I} \mathrm{mm}$ after stent placement; (e) the stricture is subsequently dilated by balloon angioplasty (arrow); (f) post-angioplasty superior vena cavogram shows decreasing residual stricture and resolution of flow limitation (arrow). The narrowest segment of the stricture is enlarged to $7.50 \mathrm{~mm}$ after balloon angioplasty 
Statistical analyses were performed by the Statistical Package for the Social Sciences (Windows version 19.0; SPSS Inc, Chicago [IL], US). P values were calculated by Fisher's exact test and MannWhitney $U$ test when appropriate, and a significance level of 0.05 was used.

\section{Results}

A total of 56 (40 male and 16 female) patients underwent 59 SVC stentings for malignant SVCO during the study period. All patients were included in the study and their mean age was 64 years (range, 48-83 years). There were no statistically significant differences in male-to-female ratio $(\mathrm{P}=0.797)$, patient age $(\mathrm{P}=0.548)$, and underlying causes between the primary and salvage stenting groups. The background demographics of the two groups of patients are summarised in Table 1.

\section{Underlying cause}

Primary lung carcinoma was the most common cause in both groups of patients, accounting for $67 \%(n=22)$ in the primary stenting group and $70 \%$ $(n=16)$ in the salvage stenting group. No statistically significant difference was seen between the two groups $(\mathrm{P}=0.768)$.

Among the causes other than primary lung carcinoma, metastatic lymphadenopathy was the most common indication, which was seen in two patients in the primary stenting group and four in the salvage stenting group. Carcinoma of the breast was the most common primary site, accounting for three of the six patients. Other causes included lymphoma $(n=1)$, malignant thymic tumour $(n=1)$, and neuroendocrine tumour $(\mathrm{n}=1)$ [Table 1].

\section{Site of obstruction}

Among the 59 stenting procedures, obstruction at the level of SVC only was most commonly encountered, accounting for $46 \%(n=16)$ of cases in the primary stenting group and $63 \%(n=15)$ of cases in the salvage stenting group. Additional sites of obstruction were found at the right brachiocephalic vein, bilateral brachiocephalic veins, and left brachiocephalic vein. There were no statistically significant differences between the two groups $(\mathrm{P}=0.633)$ [Table 2].

\section{Procedures}

Results of the procedures are summarised in Table 2. No statistically significant differences were seen between the two groups. The femoral approach was used for most patients: $86 \%(n=30)$ in the primary stenting group and $88 \%(n=21)$ in the salvage stenting group. The jugular and basilic approaches were used for the remaining patients.

Successful stent placement was achieved in all but two patients, with similar success rates in both groups of patients: $97 \%$ in the primary stenting group and $96 \%$ in the salvage stenting group $(\mathrm{P}=1.000)$. One failure occurred in the primary stenting group due to development of fatal haemopericardium during the procedure. Another failure occurred in the salvage stenting group due to failure of stent placement across the obstruction.

A single stent was sufficient to restore vessel patency in most patients, with the results comparable for both groups of patients: $82 \%(n=28)$ in the primary stenting group and $87 \% \quad(n=20)$

TABLE I. Patient characteristics by stenting group

\begin{tabular}{|c|c|c|c|c|}
\hline Characteristic & Overall $(n=56)$ & $\begin{array}{l}\text { Primary stenting } \\
\text { group }(n=33)\end{array}$ & $\begin{array}{l}\text { Salvage stenting } \\
\text { group }(n=23)\end{array}$ & $P$ value \\
\hline \multicolumn{5}{|l|}{ Sex } \\
\hline Male & 40 & 24 & 16 & 0.797 \\
\hline Female & 16 & 9 & 7 & \\
\hline Mean (range) age (years) & $64(48-83)$ & $64(50-82)$ & $63(48-83)$ & 0.548 \\
\hline \multicolumn{5}{|l|}{ Underlying cause } \\
\hline Primary lung carcinoma & 38 & 22 & 16 & 0.768 \\
\hline Other causes & 18 & 11 & 7 & \\
\hline Metastatic lymphadenopathy* & 6 & 2 & 4 & \\
\hline Breast primary & 3 & 2 & 1 & \\
\hline Lymphoma & 1 & 0 & 1 & \\
\hline Thymic tumour & 1 & 1 & 0 & \\
\hline Neuroendocrine tumour & 1 & 1 & 0 & \\
\hline Malignancy of uncertain primary & 9 & 7 & 2 & \\
\hline
\end{tabular}

* Other primary sites of metastatic lymphadenopathy included nasopharyngeal carcinoma $(n=I)$, retroperitoneal liposarcoma $(n=1)$, and ovarian adenocarcinoma $(n=1)$ 
TABLE 2. Procedure characteristics by stenting group

\begin{tabular}{|c|c|c|c|c|}
\hline Characteristic & Overall $(n=59)$ & $\begin{array}{l}\text { Primary stenting } \\
\text { group }(n=35)\end{array}$ & $\begin{array}{l}\text { Salvage stenting } \\
\text { group }(n=24)\end{array}$ & $P$ value \\
\hline \multicolumn{5}{|l|}{ Sex } \\
\hline Male & 43 & 26 & 17 & 0.770 \\
\hline Female & 16 & 9 & 7 & \\
\hline Mean age (years) & 64 & 64 & 63 & 0.552 \\
\hline \multicolumn{5}{|l|}{ Site of obstruction } \\
\hline SVC only & 31 & 16 & 15 & 0.633 \\
\hline SVC and right brachiocephalic vein & 17 & 11 & 6 & \\
\hline SVC and left brachiocephalic vein & 5 & 4 & 1 & \\
\hline SVC and bilateral brachiocephalic veins & 6 & 4 & 2 & \\
\hline \multicolumn{5}{|l|}{ Approach } \\
\hline Femoral & 51 & 30 & 21 & 1.000 \\
\hline Jugular & 7 & 4 & 3 & \\
\hline Basilic & 1 & 1 & 0 & \\
\hline Success rate & $97 \%$ & $97 \%$ & $96 \%$ & 1.000 \\
\hline Technical success & 57 & 34 & 23 & \\
\hline Technical failure & 2 & 1 & 1 & \\
\hline \multicolumn{5}{|l|}{ No. of stent placements ${ }^{*}$} \\
\hline 1 & 48 & 28 & 20 & 0.726 \\
\hline$\geq 2 \dagger$ & 9 & 6 & 3 & \\
\hline Mean (range) procedure time (mins) & $88(40-240)$ & $89(45-205)$ & $84(40-240)$ & 0.526 \\
\hline
\end{tabular}

Abbreviation: SVC = superior vena cava

* Two cases of technical failures were excluded

$\dagger$ One patient in the salvage stenting group required three stents, all others required two stents

in the salvage stenting group. No statistically significant differences were seen between the two groups $(\mathrm{P}=0.726)$. The remaining patients required placement of two to three stents to alleviate the obstruction. Anticoagulation following stent placement was recommended for prevention of instent thrombosis with the individual anticoagulation regimen decided by the senior physicians and oncologists.

The procedure times for the two groups of patients showed no statistically significant difference $(\mathrm{P}=0.526)$. The mean procedure time was 89 minutes (range, 45-205 minutes) in the primary stenting group, and 84 minutes (range, 40-240 minutes) in the salvage stenting group (Table 2).

\section{Treatment outcome}

Table 3 summarises the outcomes after SVC stenting. Resolution or improvement of symptoms within 72 hours post-stenting was demonstrated in most patients: $91 \%(n=32)$ in the primary stenting group and $96 \%(n=23)$ in the salvage stenting group $(\mathrm{P}=0.639)$. One patient in the primary stenting group had worsening symptoms after stenting due to development of in-stent thrombosis shortly after stent placement.

\section{Complications}

Procedure-related complications were uncommon and there were no statistically significant differences between the two groups of patients for complication rates: $9 \%(n=3)$ in the primary stenting group and $8 \%$ $(n=2)$ in the salvage stenting group $(P=1.000)$. The complications included haemopericardium $(n=1)$, acute pulmonary oedema $(n=1)$, and bleedingrelated complications (groin haematoma, $\mathrm{n}=2$; arterial injury, $n=1$ ). One periprocedural death occurred due to fatal haemopericardium and the overall mortality was $1.7 \%$.

For stent-related complications, in-stent thrombosis was seen in $14 \%$ of patients: $17 \%(n=6)$ in the primary stenting group and $8 \%(n=2)$ in the salvage stenting group $(\mathrm{P}=0.453)$. No stent migration was identified.

\section{Patient outcomes}

Following successful stent placement, a minority of patients had recurrence of SVCO symptoms 
TABLE 3. Outcomes of procedures by stenting group*

\begin{tabular}{|c|c|c|c|c|}
\hline Outcome & Overall $(n=59)$ & $\begin{array}{l}\text { Primary stenting } \\
\text { group }(n=35)\end{array}$ & $\begin{array}{l}\text { Salvage stenting } \\
\text { group }(n=24)\end{array}$ & $P$ value \\
\hline Symptom relief rate & $55(93 \%)$ & $32(91 \%)$ & $23(96 \%)$ & \\
\hline Symptom relief/improvement & 55 & 32 & 23 & 0.639 \\
\hline No symptom relief/improvement & 4 & 3 & 1 & \\
\hline Stable symptoms & 1 & 1 & 0 & \\
\hline Worsening symptoms & 1 & 1 & 0 & \\
\hline Technical failure & 2 & 1 & 1 & \\
\hline Procedure-related complications & $5(8 \%)$ & $3(9 \%)$ & $2(8 \%)$ & 1.000 \\
\hline Arterial injury & 1 & 1 & 0 & \\
\hline Groin haematoma & 2 & 0 & 2 & \\
\hline Acute pulmonary oedema & 1 & 1 & 0 & \\
\hline Cardiac tamponade & 1 & 1 & 0 & \\
\hline In-stent thrombosis & $8(14 \%)$ & $6(17 \%)$ & $2(8 \%)$ & 0.453 \\
\hline Re-procedure & 9 (15\%) & $6(17 \%)$ & $3(13 \%)$ & 0.725 \\
\hline Further stenting & 3 & 2 & 1 & \\
\hline Thrombolysis & 4 & 2 & 2 & \\
\hline Thrombolysis and angioplasty & 1 & 1 & 0 & \\
\hline Angioplasty & 1 & 1 & 0 & \\
\hline Survival (days) & $199(2-1156)$ & $260(5-1156) \dagger$ & $112(2-710)$ & $<0.05$ \\
\hline Alive as of 1 May $2014 \ddagger$ & 3 & 1 & 2 & 0.561 \\
\hline Lost to follow-up & 2 & 2 & 0 & 0.509 \\
\hline
\end{tabular}

requiring further interventions, including further stenting, thrombolysis, and angioplasty (Fig 2). Comparable results were seen in the two groups of patients: $17 \%(\mathrm{n}=6)$ in the primary stenting group and $13 \%(\mathrm{n}=3)$ in the salvage stenting group $(\mathrm{P}=0.725)$.

Patients in the primary stenting group had a statistically significant longer survival than patients in the salvage stenting group $(\mathrm{P}<0.05)$. The median survival was 64 (range, 5-1156) days for patients in the primary stenting group, and 62 (range, 2-710) days for patients in the salvage stenting group.

At the end of the data collection, one patient in the primary stenting group was alive 1849 days after stenting and two patients in the salvage stenting group were alive 110 days and 226 days after stenting, respectively. Two patients in the primary stenting group were lost to follow-up.

\section{Discussion}

Symptoms of SVCO usually develop over a period of 2 weeks in approximately one third of patients, and over a longer period in other patients. Oedema and distended veins are the most common symptoms and signs of SVCO of facial and arm oedema occurred in $82 \%$ and $46 \%$ of patients, respectively, and neck and chest vein distension occurred in $63 \%$ and $53 \%$ of patients, respectively. ${ }^{1}$ Respiratory symptoms and signs are common and include dyspnoea (54\%), cough (54\%), hoarseness (17\%), and stridor (4\%). Neurological symptoms and signs include syncope $(10 \%)$, headaches $(9 \%)$, dizziness $(6 \%)$, confusion $(4 \%)$, and visual symptoms $(2 \%){ }^{1}$

Malignant conditions account for about $90 \%$ of cases of SVCO in previous studies. ${ }^{12}$ Non-small-cell lung cancer is the most common cause of malignant SVCO and accounts for $50 \%$ of cases, followed by small-cell lung cancer (22\%), lymphoma (12\%), metastatic cancer $(9 \%$, of which two thirds are breast cancer), germ-cell cancer (3\%), thymoma (2\%), and mesothelioma (1\%). ${ }^{1}$ Non-malignant causes of SVCO have become more common in recent years, reflecting the increasing use of intravascular devices such as catheters and pacemakers. ${ }^{1}$ Ye et al ${ }^{13}$

have identified that most SVCOs of benign cause are related to haemodialysis catheter placement $(70 \%)$. Other causes include hypercoagulability and mediastinal fibrosis. 


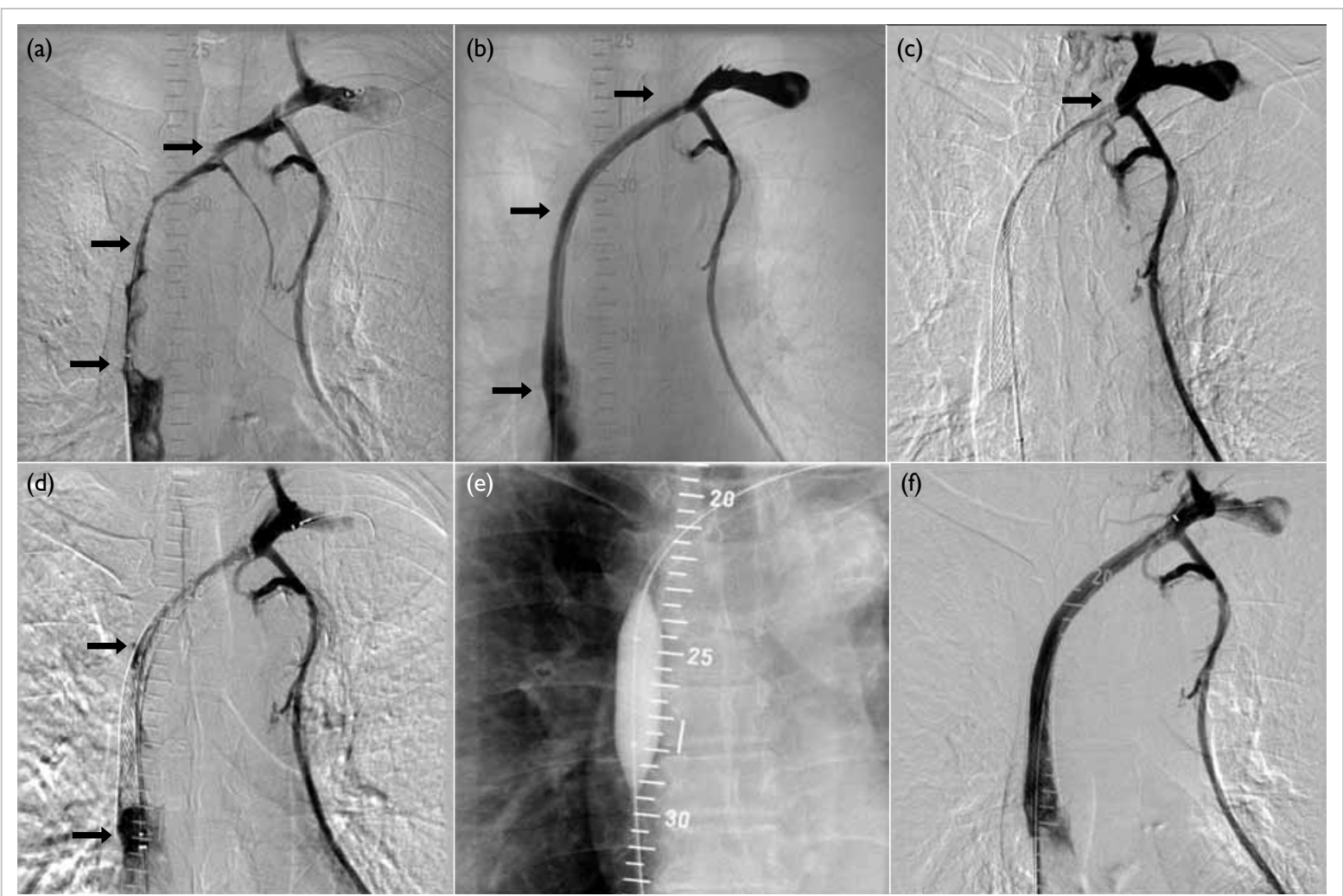

FIG 2. Superior vena cavograms showing thrombolysis for in-stent thrombosis after superior vena cava (SVC) stenting of a 67-year-old man who developed superior vena cava obstruction (SVCO) complicating a primary lung carcinoma

(a) Superior vena cavogram performed via the right femoral approach shows marked eccentric stenosis at the SVC and left brachiocephalic vein (arrows); (b) SVC stenting is subsequently performed with stent placement in the SVC and left brachiocephalic vein. Venogram performed after stent placement shows a good angiographic result with a patent stent (arrows); (c) superior vena cavogram is performed 2 days after initial stenting due to worsening SVCO symptoms, and showed an occluded stent in the SVC and left brachiocephalic vein (arrow); (d) thrombolysis was done with recombinant tissue plasminogen activator.Venogram performed after the first infusion of recombinant tissue plasminogen activator shows only a small amount of contrast passage through the previously thrombosed stent (arrows); (e) further thrombolysis with additional recombinant tissue plasminogen activator infusions and balloon angioplasties are subsequently performed; (f) post-procedural venogram confirms a patent stent with absence of in-stent thrombosis

The femoral vein is the classic route for stent insertion, and was used for most cases in the current series. Some authors have also suggested jugular vein, subclavian vein, or basilic vein access as possible options. $^{5,9,14}$ In cases of bilateral brachiocephalic vein obstruction, some authors have proposed that it is sufficient to relieve the obstruction by stent placement in either the right or left brachiocephalic vein, with collaterals allowing drainage from both sides. It has been shown that this is as clinically effective as bilateral stent placement, while offering lower cost, easier placement, and lower rates of complications and recurrence. $5,7-9$

Previous studies have shown $87 \%$ to $100 \%$ effectiveness of primary stenting in relieving SVCO. Recurrence of SVCO is seen in up to $18 \%$ of patients. ${ }^{910,15-18}$ These figures are in keeping with that shown in this study. After successful stent placement, symptoms of SVCO usually resolve within 48 to 72 hours. This is compared with radiotherapy or chemotherapy which usually take weeks to have an effect. ${ }^{1,12}$ The rapid improvement of patient's haemodynamic and performance status after primary stenting enables underlying aetiologyspecific therapy to be initiated at a full dose and in a timely manner. ${ }^{2}$ In addition, primary SVC stenting can also be performed immediately after diagnosis in the absence of a histological diagnosis, which is required for deciding the optimal treatment protocol by conventional therapy with chemotherapy and/or radiotherapy.

In patients with tumour recurrence or progression despite conventional therapy, or in patients who are not fit for chemotherapy or radiotherapy due to poor performance status or concomitant illness, salvage SVC stenting provides good palliation of SVCO symptoms. ${ }^{19}$ Most studies for salvage SVC stenting after conventional therapy 
failure report effective relief of venous compression after cancer recurrence, ranging from $81 \%$ to $100 \%$, which is similar to the findings in this study. Most studies report a recurrence rate of up to $25 \%$ but figures up to $33 \%$ to $41 \%$ have also been reported. ${ }^{2,20-27}$

A recent review article has studied complication rates after SVC stenting. ${ }^{2}$ In a total of 884 stent placements in 32 studies, the mortality was $2 \%$, which is similar to that in this study. A total of $41 \%$ of the deaths were due to severe haemorrhage such as pulmonary or cerebral haemorrhage, and $23 \%$ were due to acute cardiac events, including arrhythmia, myocardial infarction, and cardiac tamponade. Other causes included respiratory failure (17\%) and pulmonary embolism (6\%). ${ }^{2}$ Cardiac tamponade following rupture of central veins, which was seen in this series, is rare, but can be rapidly fatal. ${ }^{28}$ For this reason, it has been suggested that facilities for pericardial drainage should be available in the room to allow emergent pericardiocentesis. ${ }^{12}$

Periprocedural and post-procedural complications are low and were found in up to $19 \%$ of patients in previous studies. ${ }^{12}$ Overall, these complications compare very favourably with those of chemotherapy and radiotherapy. ${ }^{4}$ The most common major complications are stent malposition or migration, accounting for $47 \%$ of all complications, followed by bleeding (21\%), deep vein thrombosis (10\%), pulmonary oedema (8\%), arrhythmia (5\%), infection (5\%), and pulmonary embolism (3\%). ${ }^{2}$

For stent-related complications, a series by Lanciego et $\mathrm{al}^{7}$ reviewed 149 patients with Wallstent placement for SVC syndrome, which demonstrated a $10.7 \%$ rate of stent occlusion (complete, $8 \%$; partial, 2.7\%), $2.7 \%$ stent thrombosis, $2.7 \%$ stent shortening, and $0.7 \%$ stent migration.

Although commonly given for patients after SVC stent placement, the effectiveness of anticoagulation has not been clearly proven. In general, anticoagulation is recommended at least for the first month after stent placement due to the high thrombogenic effect of the stent before neoendothelium covers the endovascular surface. ${ }^{7} \mathrm{~A}$ range of 1 to 9 months of anticoagulation has been proposed and no consensus is currently available. ${ }^{13}$

Patient survival is generally short and is related to the usual status of locally advanced or metastatic malignancy causing SVCO. As demonstrated in this study, survival was shorter in patients receiving salvage stenting after failure of conventional therapy (mean, 3.7 months) compared with that of patients receiving primary stenting before conventional therapy (mean, 8.7 months). This is likely due to the difference in underlying disease status between the two groups of patients. In a previous report, overall patient survival was approximately 6 months after SVC stenting, ${ }^{7}$ which is similar to the overall mean survival identified in this series (6.6 months).
There are a few limitations to this study. As a retrospective study, there was a lack of standardised selection criteria for the choice between primary SVC stenting and conventional therapy by radiotherapy and/or chemotherapy for patients presenting with SVCO. There was also a lack of standardised grading system of the degree of SVCO symptoms and follow-up protocol. The decisions for angioplasty before and after stent placement were made by the operating radiologists during the procedure, and the post-stenting anticoagulation regimen was also decided individually by the senior physicians and oncologists. The small sample size might have limited the power of the study. There are also possibilities of information bias during the review process. These should serve as future references for performing a prospective study with a standardised protocol to evaluate the results of SVC stenting in different groups of patients.

\section{Conclusion}

Stenting of SVC is a safe and effective means of alleviating SVCO symptoms both in patients undergoing primary stenting before conventional therapy and in those undergoing salvage stenting after failure of conventional therapy. The number of stents required, success rates, procedure times, symptom relief rates, complication rates, and reprocedure rates showed no statistically significant difference between these two groups of patients.

\section{Declaration}

All the authors have no potential conflict of interest to declare.

\section{References}

1. Wilson LD, Detterbeck FC, Yahalom J. Clinical practice. Superior vena cava syndrome with malignant causes. N Engl J Med 2007;356:1862-9.

2. Nguyen NP, Borok TL, Welsh J, Vinh-Hung V. Safety and effectiveness of vascular endoprosthesis for malignant superior vena cava syndrome. Thorax 2009;64:174-8.

3. Charnsangavej $\mathrm{C}$, Carrasco $\mathrm{CH}$, Wallace $\mathrm{S}$, et al. Stenosis of the vena cava: preliminary assessment of treatment with expandable metallic stents. Radiology 1986;161:295-8.

4. Rowell NP, Gleeson FV. Steroids, radiotherapy, chemotherapy and stents for superior vena caval obstruction in carcinoma of the bronchus: a systematic review. Clin Oncol (R Coll Radiol) 2002;14:338-51.

5. Ganeshan A, Hon LQ, Warakaulle DR, Morgan R, Uberoi R. Superior vena caval stenting for SVC obstruction: current status. Eur J Radiol 2009;71:343-9.

6. Fagedet D, Thony F, Timsit JF, et al. Endovascular treatment of malignant superior vena cava syndrome: results and predictive factors of clinical efficacy. Cardiovasc Intervent Radiol 2013;36:140-9.

7. Lanciego C, Pangua C, Chacón JI, et al. Endovascular stenting as the first step in the overall management of malignant superior vena cava syndrome. AJR Am J 
Roentgenol 2009;193:549-58.

8. Dinkel HP, Mettke B, Schmid F, Baumgartner I, Triller J, Do DD. Endovascular treatment of malignant superior vena cava syndrome: is bilateral wallstent placement superior to unilateral placement? J Endovasc Ther 2003;10:788-97.

9. Lanciego C, Chacón JL, Julián A, et al. Stenting as first option for endovascular treatment of malignant superior vena cava syndrome. AJR Am J Roentgenol 2001;177:58593.

10. Nagata T, Makutani S, Uchida H, et al. Follow-up results of 71 patients undergoing metallic stent placement for the treatment of a malignant obstruction of the superior vena cava. Cardiovasc Intervent Radiol 2007;30:959-67.

11. Nicholson AA, Ettles DF, Arnold A, Greenstone M, Dyet JF. Treatment of malignant superior vena cava obstruction: metal stents or radiation therapy. J Vasc Interv Radiol 1997;8:781-8.

12. Uberoi R. Quality assurance guidelines for superior vena cava stenting in malignant disease. Cardiovasc Intervent Radiol 2006;29:319-22.

13. Ye $M$, Shi $Y X$, Huang XZ, Zhao YP, Zhang $H$, Zhang JW. Endovascular recanalization of superior vena cava, brachiocephalic, and subclavian venous occlusions caused by nonmalignant lesions. Chin Med J 2012;125:1767-71.

14. Miller JH, McBride K, Little F, Price A. Malignant superior vena cava obstruction: stent placement via the subclavian route. Cardiovasc Intervent Radiol 2000;23:155-8.

15. Chatziioannou A, Alexopoulos T, Mourikis D, et al. Stent therapy for malignant superior vena cava syndrome: should be first line therapy or simple adjunct to radiotherapy. Eur J Radiol 2003;47:247-50.

16. Bierdrager E, Lampmann LE, Lohle PN, et al. Endovascular stenting in neoplastic superior vena cava syndrome prior to chemotherapy or radiotherapy. Neth J Med 2005;63:203.

17. Gross CM, Krämer J, Waigand J, et al. Stent implantation in patients with the superior vena cava syndrome. AJR Am J Roentgenol 1997;169:429-32.
18. Chacón López-Muñiz JI, García García L, Lanciego Pérez $C$, et al. Treatment of superior and inferior vena cava syndromes of malignant cause with Wallstent catheter placed percutaneously. Am J Clin Oncol 1997;20:293-7.

19. Urruticoechea A, Mesia R, Dominguez J, et al. Treatment of malignant superior vena cava syndrome by endovascular stent insertion. Experience on 52 patients with lung cancer. Lung Cancer 2004;43:209-14.

20. Kee ST, Kinoshita L, Razavi MK, Nyman UR, Semba CP, Dake MD. Superior vena cava syndrome: treatment with catheter-directed thrombolysis and endovascular stent placement. Radiology 1998;206:187-93.

21. Marcy PY, Magné N, Bentolila F, Drouillard J, Bruneton JN, Descamps B. Superior vena cava obstruction: is stenting necessary? Support Care Cancer 2001;9:103-7.

22. Greillier L, Barlési F, Doddoli C, et al. Vascular stenting for palliation of superior vena cava obstruction in non-smallcell lung cancer patients: a future 'standard' procedure? Respiration 2004;71:178-83.

23. García Mónaco R, Bertoni H, Pallota G, et al. Use of selfexpanding vascular endoprosthesis in superior vena cava syndrome. Eur J Cardiothorac Surg 2003;24:208-11.

24. Tanigawa N, Sawada S, Mishima K, et al. Clinical outcome of stenting in superior vena cava syndrome associated with malignant tumors. Comparison with conventional treatment. Acta Radiol 1998;39:669-74.

25. Courtheoux P, Alkofer B, Al Refaï M, Gervais R, Le Rochais JP, Icard P. Stent placement in superior vena cava syndrome. Ann Thorac Surg 2003;75:158-61.

26. Crowe MT, Davies CH, Gaines PA. Percutaneous management of superior vena cava occlusions. Cardiovasc Intervent Radiol 1995;18:367-72.

27. Furui S, Sawada S, Kuramoto K, et al. Gianturco stent placement in malignant caval obstruction: analysis of factors for predicting the outcome. Radiology 1995;195:147-52.

28. Ploegmakers MJ, Rutten MJ. Fatal pericardial tamponade after superior vena cava stenting. Cardiovasc Intervent Radiol 2009;32:585-9. 